\title{
KEBIJAKAN PENDIDIKAN DALAM PERSPEKTF PERAN BIROKRASI DAN PARTISIPASI MASYARAKAT
}

\author{
Erma Fatmawati \\ Institut Agama Islam Ibrahimy Genteng Banyuwangi \\ fatmawatierma@gmail.com
}

\begin{abstract}
Abstrak
Pendidikan sejatinya tidak bisa lepas dari peran aktif masyarakat. Oleh sebab itu, dibutuhkan kebijakan dan peran berokrasi yang mampu mengakomudasi seluruh aspirasi serta keterlibatan masyarakat. Selama ini rantai berokrasi cukup panjang dan persoalannyapun kompleks sehingga menambah beban peningkatan mutu pendidikan. Kajian ini difokuskan pada bagaimana kebijakan pendidikan dilihat dari peran birokrasi dan partisipasi masyarakat, yang bertujuan untuk mengetahui kebijakan pendidikan bila dilihat dari peran birokrasi dan partisipasi masyarakat. Penelitian ini menggunakan metode kualitatif kepustakaan, dengan pengumpulan data menggunakan studi dokumenter sedangkan analisis datanya menggunakan content analysis. Hasil kajian ini adalah dibutuhkan birokrasi pendidikan adaptif dengan perubahan lingkungan dan responsif terhadap kebutuhan masyarakat. Kinerja birokrasi harus ditingkatkan untuk menciptakan pelayanan prima pada kepentingan publik. Lembaga pendidikan perlu diberi apresiasi dan dijauhkan dari ekploitasi dan kepentingan politik etis. Peran birokrasi di lembaga pendidikan dapat menjadi model implementasi kebijakan pada satuan dan jenjang pendidikan sehingga dibutuhkan pembaharuan manajemen. inovasi manajemen menjadi suatu keniscayaan dalam menyelesaikan persoalan-yang ada. Problem tersebut dapat berupa pemerataan pendidikan, peningkatan mutu, peningkatan efisiensi dan efektifitas serta relevansi yang bertujuan agar penyebaran ide inovasi dapat diadopsi, dimanfaatkan dan didesiminasikan untuk perbaikan dan pemecahan problem pendidikan.
\end{abstract}

Kata Kunci: birokrasi, kebijakan, partisipasi masyarakat 


\begin{abstract}
Education, essentially, cannot be separated from the active role of the community. For this reason, such policies and the role of bureaucracy which is able to accommodate all aspirations and community involvement are needed. All this time, the bureaucracy chain was recognized to be too long and the complexity of the problems adds up to the burden of improving the quality of education. This study focuses on how education policy viewed from the role of bureaucracy and community participation. This study uses a qualitative library method. The data collection method used in this study is documentary studies while the analysis method uses is content analysis. The results of this study revealed that adaptive education bureaucracy with environmental changes and responsiveness to community needs are essentially needed. Bureaucratic performance must be improved to create an excellent service in the public interest. Educational institutions need to be appreciated and kept away from exploitation as well as ethical political interests. The role of bureaucracy in educational institutions can be seen as a model of policy implementation at education units and levels so that the management reformation is needed. Management innovation becomes a necessity in solving existing problems. The problem itself can be in the form of equitable education, quality improvement, efficiency and effectiveness improvement and relevance which aims to spread the idea of innovation to be adopted, utilized and disseminated to improve and solve educational problems.
\end{abstract}

Keywords: bureaucracy, policy, community involvement

\title{
Pendahuluan
}

Negara memiliki wewenang merumuskan dan menjalankan kebijakan, termasuk kebijakan di bidang pendidikan. Kebijakan bidang pendidikan yang memenuhi langit harapan masyarakat Indonesia adalah terpenuhinya pendidikan yang unggul bagi seluruh lapisan masyarakat hingga simpul paling bawah. Kebijakan pendidikan bukan tidak mungkin menjadi bagian kebijakan publik dalam arti yang sesungguhnya, yakni melibatkan peran serta rakyat dalam menentukan cita-cita sosial (social ideals) secara kolektif dalam menentukan kebijakan pendidikan di negara mereka sendiri.

Terkait hal ini, Syaefudin Sa'ud dan Abin Syamsuddin Makmun menyatakan:

"Kekuasaan kebijakan mencakup setiap hukum yang memperhatikan kesejahteraan semua orang dalam negaranya atau setiap individu di dalamnya, apakah berkaitan dengan hak-hak atau kewajibannya, apakah 
penghargaan sebagai individu atau warga negara, hak-hak individu atau kekayaan seluruh orang dalam negaranya atau setiap individu di dalamnya. Kekuasaan kebijakan adalah kekuasaan negara untuk membatasi hak-hak individu atas kepentingan kelompok sosial karena mempertimbangkan kesehatan masyarakat, keamanan, kesejahteraan atau moral. ${ }^{1}$

Implementasi kebijakan mengacu pada sistem pengelolaan urusan-urusan publik. Pengelolaan urusan-urusan publik diwujudkan dalam bentuk good governance yang memerlukan adanya reformasi kelembagaan dan reformasi manajemen publik. Reformasi kelembagaan menyangkut pembenahan seluruh alat-alat pemerintahan di daerah baik struktur maupun infrastrukturnya. Kunci reformasi kelembagaan ini adalah masyarakat umum (Dewan Pendidikan, Lembaga Swadaya Masyarakat misalnya sebagai stakeholders, pemerintah atau negara sebagai eksekutif dan MPRDPR/D sebagai shareholders. ${ }^{2}$ Sementara itu, reformasi manajemen sektor publik terkait dengan perlunya digunakan model manajemen pemerintah yang baru atau terbarukan (dinamis) yang sesuai dengan tuntutan perkembangan zaman, tidak sekedar perubahan paradigma (worldview) namun juga perubahan manajemen/tata kelola/administratif sehingga peran birokrasi berjalan sesuai harapan.

Dalam Keputusan Menteri Pemberdayaan Aparatur Negara Nomer 63/Kep./M.PAN/7/20033 tentang Pedoman Umum Penyelenggaraan Layanan Publik, disebutkan bahwa layanan publik oleh pemerintah dibedakan menjadi tiga kelompok layanan administratif. Pertama, kelompok layanan yang menghasilkan bentuk dokumen resmi yang dibutuhkan oleh publik. Kedua, kelompok layanan yang menghasilkan berbagai bentuk/jenis barang yang digunakan oleh publik. Ketiga, kelompok layanan yang menghasilkan berbagai jasa yang dibutuhkan oleh publik. Layanan publik dalam hal ini dipahami sebagai segala kegiatan yang

${ }^{1}$ Syaefudin Sa'ud dan Abin Syamsuddin Makmun, Perencanaan Pendidikan: Suatu Pendekatan Komprehensif (Bandung: PT. Remaja Rosdakarya, 2006), 186.

2 Lihat Endro Sumarjo, "Aktualisasi Nilai-nilai Good Governance dalam Penyelenggaraan Pemerintah dan Pembangunan," dalam Jurnal Hukum dan HAM Bidang Pendidikan Vol. 2 No. 1 April 2004, 1-13.

3 Keputusan Menteri Pendayagunaan Aparatur Negara Nomor: 63/Kep/M.Pan/7/2003 tentang Pedoman Umum Penyelengaraan Pelayanan Publik Menteri Pendayagunaan Aparatur Negara, 1-11. 
dilaksanakan oleh institusi pendidikan dalam rangka pencerdasan masyarakat sebagai pelaksanaan ketentuan peraturan perundangundangan.

Dalam hal ini, paling tidak terdapat tiga pelaku yaitu: pembuat kebijakan, penyedia/pelaksana layanan publik, dan penerima layanan. Dalam sistem pemerintahaan dominan, perumus dan pelaksana layanan publik dilakukan oleh pemerintah, dan masyarakat sebagai penerima layanan. Tetapi, pelayanan publik oleh birokrasi seharusnya digerakkan oleh visi dan misi pelayanan, namun pada kenyataannya justru digerakkan oleh peraturan dan anggaran yang tidak dimengerti oleh publik karena tidak disosialisasikan secara transparan. ${ }^{4}$ Implementasi kebijakan merupakan sebuah proses panjang bagaimana para pelaku kebijakan menjalankan juga turut serta menjalankan keputusan kebijakan. Keseluruhan tindakan para pemangku kepentingan diarahkan menuju pencapaian tujuan kebijakan.

\section{Pembahasan}

\section{Implementasi Kebijakan Pendidikan}

Istilah kebijakan (policy) seringkali dicampuradukkan dengan kebijaksanaan (wisdom). Landasan utama yang mendasari suatu kebijakan adalah pertimbangan akal. Tentunya suatu kebijakan bukan semata-mata merupakan hasil pertimbangan akal manusia. Namun, akal manusia merupakan unsur yang dominan di dalam mengambil keputusan dari berbagai pilihan dalam pengambilan keputusan kebijakan.

Kebijakan publik menurut Winarno sebagaimana dikutip oleh Muhammad Munadi dan Barnawi adalah kebijakan yang dikembangkan oleh lembaga-lembaga pemerintah dan pejabatpejabat pemerintah yang dipengaruhi oleh aktor-aktor dan faktorfaktor bukan pemerintah. Maksud dari ungkapan ini ialah bahwa kebijakan tidak semata-mata didominasi oleh kepentingan pemerintah, aktor-aktor diluar pemerintah harus diperhatikan aspirasinya, dan faktor-faktor yang berpengaruh harus dikaji sebelumnya. ${ }^{5}$ Kebijakan juga merupakan serangkaian proses dari suatu perencanaan dan perumusan oleh suatu kelompok atau

${ }^{4}$ Agus Dwiyanto dkk., Reformasi Birokrasi Publik di Indonesia, (Yogyakarta: Penerbit PSKK-UGM, 2002), 84.

${ }^{5}$ Muhammad Munadi dan Barnawi, Kebijakan Publik di Bidang Pendidikan (Yogyakarta: Ar-Ruzz Media, 2011), 17. 
lembaga/instansi pemerintah yang berupa peraturan atau program untuk menyelesaikan suatu permasalahan.

Menurut Nanang Fatah, terdapat tiga elemen kebijakan yaitu pelaku kebijakan, lingkungan kebijakan, dan kebijakan publik. Pelaku kebijakan, misalnya kelompok warga negara, perserikatan buruh, partai politik, agen-agen pemerintah, pemimpin terpilih dan para analisis kebijakan sendiri. Lingkungan kebijakan, yaitu konteks khusus dimana kejadian-kejadian di sekeliling isu kebijakan terjadi, mempengaruhi dan dipengaruhi oleh pembuat kebijakan berisi proses yang bersifat dialektis, yang berarti bahwa dimensi objektif dan subjektif dari pembuat kebijakan tidak terpisahkan di dalam prakteknya.

Sistem kebijakan adalah produk manusia yang subjektif yang diciptakan melalui pilihan-pilihan yang sadar para pelaku kebijakan ${ }^{6}$. Adapun kebijakan publik di bidang pendidikan dapat didefinisikan sebagai keputusan yang diambil bersama antara pemerintah $^{7}$ dan aktor di luar pemerintah dan mempertimbangkan faktor-faktor yang mempengaruhinya untuk dilaksanakan atau tidak dilaksanakan pada bidang pendidikan bagi seluruh warga masyarakat. Kebijakan publik bidang pendidikan meliputi anggaran pendidikan, kurikulum, rekrutmen tenaga kependidikan, pengembangan profesional staf, tanah dan bangunan, pengelolaan sumber daya, dan kebijakan lain yang bersentuhan langsung maupun tidak langsung atas pendidikan. ${ }^{8}$

H.A.R Tilaar memberikan makna yang sedikit berbeda tentang kebijakan pendidikan. Menurutnya, kebijakan pendidikan merupakan rumusan dari berbagai cara untuk mewujudkan tujuan pendidikan nasional, diwujudkan atau dicapai melalui lembagalembaga sosial (social institutions) atau organisasi sosial dalam bentuk lembaga-lembaga pendidikan formal, nonformal, dan

6 Nanang Fatah, Analisis Kebijakan Pendidikan, (Bandung: Remaja Rosdakarya, 2013), 136.

${ }^{7}$ Dalam Peraturan Pemerintah Republik Indonesia Nomor 17 Tahun 2010 Bab II Pasal 2 dituliskan bahwasanya Pengelolaan pendidikan dilakukan oleh: a. Pemerintah; b. pemerintah provinsi; c. pemerintah kabupaten/kota; d. penyelenggara satuan pendidikan yang didirikan masyarakat; dan e. satuan atau program pendidikan. Adapun dalam Pasal 4 dinyatakan bahwa pengelolaan pendidikan didasarkan pada kebijakan nasional bidang pendidikan sesuai dengan ketentuan peraturan perundang-undangan. Peraturan Pemerintah Republik Indonesia Nomor 17 Tahun 2010 tentang Pengelolaan dan Penyelenggaraan Pendidikan, 10-11.

${ }^{8}$ Munadi dan Barnawi, Kebijakan Publik di Bidang Pendidikan, 19. 
informal. 9 Dengan demikian, dapat kita pahami suatu kebijakan apabila tidak segera diimplementasikan, maka tidak akan dapat diketahui tingkat keberhasilannya untuk orang banyak. Kebijakan hanya akan menjadi rencana konseptual yang akan tersimpan rapi dalam tumpukan arsip-arsip saja.

Dalam kajian implementasi pendidikan, ada beberapa rujukan teoritis tentang implementasi pendidikan ini. Dalam kamus Webster sebagaimana dikutip Sudiyono menyebutkan bahwa "to implement berarti to provide the means for carrying out", mengimplementasikan berarti melengkapi atau menyediakan sarana untuk melaksanakan sesuatu. Linberry menyatakan bahwa implementasi mencakup komponen berikut:

Pertama, menciptakan dan menyusun staf sebuah agen baru untuk melaksanakan sebuah kebijakan baru; kedua, menterjemahkan tujuan legislatif dan serius memasukkannya ke dalam aturan pelaksanaan, mengembangkan panduan atau kerangka kerja bagi para pelaksana kebijakan; ketiga, melakukan koordinasi terhadap sumberdaya agen dan pembiayaan bagi kelompok sasaran, mengembangkan pembagian tanggungjawab para agen dan antar para agen serta hubungan antar agen; keempat, mengalokasikan sumberdaya untuk memperoleh dampak kebijakan. ${ }^{10}$

Menurut Van Meter dan Van Horn seperti yang dikutip Arif Rohman, implementasi kebijakan dimaksudkan sebagai keseluruhan tindakan yang dilakukan oleh individu-individu (pejabat-pejabat) atau kelompok-kelompok pemerintah atau swasta yang diarahkan kepada pencapaian tujuan kebijakan yang telah ditentukan terlebih dahulu. Maksudnya tindakan di sini adalah tindakan-tindakan yang merupakan usaha sesaat untuk menstransformasikan keputusan ke dalam istilah operasional, maupun usaha berkelanjutan untuk mencapai perubahanperubahan besar dan kecil yang diamanatkan oleh keputusankeputusan kebijakan. ${ }^{11}$ Sementara itu, menurut James E. Anderson dalam seperti yang dikutip Sudiyono menyatakan, bahwa implementasi kebijakan mencakup empat aspek, yaitu: (1) siapa

${ }^{9}$ H.A.R Tilaar, Kekuasaan dan Pendidikan: Manajemen Pendidikan Nasional dalam Pusaran Kekuasaan, (Jakarta: Rineka Cipta, 2009), 7.

${ }^{10}$ Sudiyono dan Mada Sutapa, Kebijakan Pendidikan, 80.

${ }^{11}$ Arif Rohman, Politik Ideologi Pendidikan (Yogyakarta: LaksBang Mediatama, 2009), 134. 
yang terlibat dalam implementasi kebijakan; (2) esensi proses administratif; (3) kepatuhan terhadap kebijakan; (4) pengaruh implementasi pada isi dan dampak kebijakan. ${ }^{12}$

Van Meter dan Van Horn mengawali gagasan teorinya tentang implementasi dengan menyampaikan enam variabel, yang meliputi: (1) stanndar dan tujuan kebijakan; (2) sumberdaya; (3) komunikasi; (4) interorganisasi dan aktivitas pengukuhan; (5) karakteristik agen pelaksana; (6) kondisi sosial, ekonomi, dan politik, serta karakter pelaksana. Menurut M. Grindle menambahkan, bahwa proses implementasi mencakup tugas-tugas membentuk suatu ikatan yang memungkinkan arah suatu kebijakan dapat direalisasikan sebagai hasil dari aktivitas pemerintah. Seorang ahli yang bernama Charles O. Jones mendasarkan diri pada konsepsi aktivitas-aktivitas fungsional. Menurutnya, implementasi adalah suatu aktivitas yang dimaksudkan untuk mengoperasikan sebuah program.

Ada tiga pilar aktivitas dalam mengoperasikan program tersebut adalah: pertama, pengorganisasian, pembentukan atau penataan kembali sumberdaya, unit-unit serta metode untuk menjalankan program agar bisa berjalan; kedua, interpretasi, yaitu aktivitas menafsirkan agar program menjadi rencana dan pengarahan yang tepat dan dapat diterima serta dilaksanakan; ketiga, aplikasi, yaitu berhubungan dengan perlengkapan rutin bagi pelayanan, pembayaran, atau lainnya yang disesuaikan dengan tujuan atau perlengkapan program. ${ }^{13}$

Dari beberapa ulasan di atas dapat disimpulkan bahwa implementasi kebijakan merupakan suatu cara untuk melaksanakan suatu kebijakan untuk dapat mencapai tujuan yang telah ditentukan. Kebijakan di bidang pendidikan digunakan untuk memahami kebijakan itu sendiri yang sebenarnya merupakan bagian dari kebijakn publik.

Dalam implementasi kebijakan terdapat faktor-faktor yang mempengaruhi implementasi suatu kebijakan. Implementasi kebijakan akan menghasilkan keberhasilan yang diharapkan oleh pembuat kebijakan dan kelompok yang menjadi sasaran kebijakan tersebut. Arif Rohman menyatakan, bahwa ada tiga faktor yang yang dapat menentukan kegagalan dan keberhasilan dalam inplementasi kebijakan yaitu: (1) faktor yang terletak pada rumusan

\footnotetext{
${ }^{12}$ Arif Rohman, Politik Ideologi Pendidikan, 81.

${ }^{13}$ Arif Rohman, Politik Ideologi Pendidikan, 134-135, 137.
} 
kebijakan yang telah dibuat oleh para pengambil keputusan, menyangkut kalimatnya jelas atau tidak, sasarannya tepat atau tidak, mudah dipahami atau tidak, mudah diinterpretasikan atau tidak, dan terlalu sulit dilaksanakan atau tidak; (2) faktor yang terletak pada personil pelaksana, yakni yang menyangkut tingkat pendidikan, pengalaman, motivasi, komitmen, kesetiaan, kinerja, kepercayaan diri, kebiasaan-kebiasaan, serta kemampuan kerjasama dari para pelaku pelaksana kebijakan. Termasuk dalam personil pelaksana adalah latar belakang budaya, bahasa, serta ideologi kepartaian masing-masing semua itu akan sangat mempengaruhi cara kerja mereka secara kolektif dalam menjalankan misi implementasi kebijakan; (3) faktor yang terletak pada sistem organisasi pelaksana, yakni menyangkut jaringan sistem, hirarki kewenangan masing-masing peran, model distribusi pekerjaan, gaya kepemimpinan dari pemimpin organisasinya, aturan main organisasi, target masing-masing tahap yang ditetapkan, model monitoring yang biasa dipakai, serta evaluasi yang dipilih. ${ }^{14}$

Kemudian, menurut Sabatier dan Mazmanian sebagaimana dikutip oleh Sudiyono dan Mada Sutapa mengemukakan lima faktor pendukung agar implementasi dapat dilaksanakan secara optimal, yaitu: (1) Program harus mendasarkan diri pada sebuah kajian teori yang terkait dengan perubahan pelaku kelompoksasaran guna mencapai hasil yang telah ditetapkan. Kebanyakan pengambilan atau perumusan kebijakan didasarkan pada teori sebab akibat. Teori ini terdiri dua bagian, bagian pertama adanya keterkaitan antara pencapaian dengan tolak ukur atau hasil yang diharapkan. Bagian kedua khusus mengenai cara pelaksanaan kebijakan yang dapat dilakukan oleh kelompok sasaran; (2) Undang-undang atau peraturan tidak boleh ambigu atau bermakna ganda. Dalam hal ini pemerintah harus dapat mengkaji ulang produk- produk hukum. Sasaran kebijakan harus memiliki derajat ketepatan dan kejelasan, dimana keduanya berlaku secara internal maupun dalam keseluruhan program yang dilaksanakan oleh pihak pelaksana; (3) Para pelaku kebijakan harus memiliki kemempuan manajerial, dan politis dan komitmen terhadap tujuan yang akan dicapai. Para pemimpin dan perumus kebijakan dapat mengambil langkah baik pada ranah merencanakan sebuah peraturan maupun dalam pengangkatan personil baru non layanan masyarakat, guna

${ }^{14}$ Arif Rohman, Politik Ideologi Pendidikan, 147. 
meningkatkan isi dan keterdukungan pemimpin terhadap pancapaian tujuan Undang-undang; (4) Program harus didukung oleh para pemangku kepentingan, perumus undang-undang, pengadilan yang mendukung; (5) Prioritas umum dari sasaran perundang-undangan tidak signifikan direduksi oleh waktu dengan adanya kebijakan yang sangat darurat pada publik, atau perubahan keadaan sosial ekonomi yang sesuai dan didasarkan pada teori perundang-undangan secara teknis ataupun memperoleh dukungan publik. ${ }^{15}$

Implementasi kebijakan publik sebagaimana paparan di atas, tentu saja termasuk di dalamnya mencakup implementasi kebijakan pendidikan yang dalam proses pembuatannnya melalui tahapan yang panjang. Winarno dan Dunn membaginya menjadi lima tahapan, yaitu penyusunan agenda, formulasi kebijakan implementasi kebijakan itu sendiri, dan penilaian kebijakan. Sedangkan menurut Devine implementasi kebijakan pendidikan dalam proses dan prakteknya memiliki empat dimensi pokok, yaitu (1) dimensi normatif; nilai, standart dan filsafat, (2) struktural; desentralisasi, sentalisasi, federal atau bentul lain, (3) konsituentif; individu, kelompok kepentingan, dan penerima yang menggunakan kekuatan untuk mempengaruhi proses pembuatan kebijakan, dan (4) teknis; praktek, implentasi dan penilaian dari pembuatan kebijakan pendidikan. ${ }^{16}$

Pemerintah sendiri melalui Peraturan Pemerintah Republik Indonesia Nomor 17 Tahun 2010 tentang Pengelolaan dan Penyelenggaraan Pendidikan membuat formulasi yang jelas sebagai tata laksana pengelolaan pendidikan yang dalam manajemen pendidikan nasional sebagai sains dan praktek berkaitan dengan implementasi kebijakan pendidikan maupun pelaksanaan program yang dijabarkan dari kebijakan-kebijakan tersebut.

\section{Birokrasi Pendidikan di Indonesia}

Kehadiran birokrasi sebenarnya dipergunakan untuk mengatur suatu pekerjaan yang beraneka ragam yang menyangkut kepentingan orang banyak agar bisa terlaksana dan melayani semua golongan dengan baik, efektif, dan mudah. Akan tetapi, dalam perkembangannya, sampai sekarang birokrasi telah menjadi

\footnotetext{
15 Sudiyono dan Mada Sutapa, Kebijakan Pendidikan, 90-100.

${ }^{16}$ Munadi dan Barnawi, Kebijakan Publik di Bidang Pendidikan, 19-20.
} 
momok bagi manusia modern, yang selalu ingin dihindari dan dijauhi. ${ }^{17}$

Lebih jauh Muhammad Rifai mengungkapkan tentang fokus utama Rencana Strategis (Renstra) Kemendiknas 2010-2014 adalah memberikan pelayanan yang berhubungan dengan birokrasi pendidikan nasional. Sebagaimana yang kita ketahui bersama, kelahiran orde reformasi adalah respons atas buruknya birokrasi pada masa orde baru. Namun nyatanya, birokrasi pada masa orde reformasi tidaklah jauh berbeda. Masih menurut Rifai, di dalam Renstra Kemendiknas tersebut dikatakan bahwa persoalan birokrasi pendidikan berkaitan dengan reformasi birokrasi yang merupakan inti dari berbagai program prioritas guna meningkatkan kualitas pelayanan publik. Kemendiknas menjadi salah satu Kementerian yang harus menyelesaikan reformasi birokrasi. Reformasi birokrasi sangat diperlukan sejalan dengan tanggungjawab yang semakin besar karena harus mengelola anggaran pendidikan sebesar 20\% dari APBN/APBD. Berdasarkan kajian awal reformasi birokrasi pada tahun 2009, reformasi birokrasi dilaksanakan antara lain melalui kebijakan-kebijakan sebagai berikut: (1) restrukturasi organisasi yang mendukung visi dan misi Kemendiknas, (2) penyempurnaan tata laksana, (3) peningkatan kualitas sumber daya manusia, (4) pengembangan sistem pengukuran dan remunerasi berbasis kinerja, dan (5) pemantauan dan evaluasi pelaksanaan reformasi birokrasi. ${ }^{18}$

Visi yang tertuang dalam Renstra Kemendiknas 2010-2014 yaitu terselenggaranya layanan prima pendidikan nasional untuk membentuk insan Indonesia cerdas komprehensif. Layanan prima di bidang pendidikan nasional tersebut meliputi aspek-aspek

17 Muhammad Rifai, Politik Pendidikan Nasional, (Yogyakarta: Ar-Ruzz Media, 2011), 61. Di dalam Webster's Dictionary, Istilah birokrasi (bureaucracy) diartikan sebagai, "The Administration of government through departments and subdivisions managed by sets of officials following an inflexible routine (administrasi pemerintah melalui beberapa departemen dan beberapa sub bagian yang dikelola oleh kelompok pejabat untuk mengikuti rutinitas yang kaku)".

${ }^{18}$ Lihat juga Rencana Strategis Departemen Pendidikan Nasional Tahun 20102014, 110-111. Dalam Peningkatan profesionalisme dan kinerja tenaga kependidikan melalui reformasi birokrasi dan manajemen pembinaan kepegawaian diharapkan akan mampu mendukung pembangunan pendidikan. Pemerintah memprioritaskan atau menargetkan reformasi birokrasi pada semua kementerian dan lembaga selesai pada tahun 2011. Reformasi birokrasi menjadi suatu keharusan sejalan dengan reformasi perencanaan pembangunan menuju Performance Based Budgeting (PBB). Rencana Strategis Departemen Pendidikan Nasional Tahun 2010-2014, 65. 
berikut: (1) tersedia secara merata di seluruh Indonesia; (2) terjangkau oleh seluruh lapisan masyarakat; (3) berkualitas dan relevan dengan kebutuhan kehidupan bermasyarakat, dunia usaha dan dunia industri; (4) setara bagi warga negara Indonesia dalam memperoleh pendidikan berkualitas dengan memperhatikan keberagaman latar belakang sosial budaya, ekonomi, geografi, gender dan sebagainya; (5) menjamin kepastian bagi warga negara Indonesia untuk mengenyam pendidikan dan menyesuaikan diri dengan tuntutan masyarakat, dunia usaha dan dunia industri.

Berkaitan dengan Renstra Kemendiknas 2010-2014, kebijakan pendidikan di Indonesia sebagaimana yang dituangkan dalam Program Pembangunan Nasional lima tahun (Propenas), ${ }^{19}$ ditetapkan oleh Presiden bersama DPR menghendaki pentingnya desentralisasi pendidikan atau otonomi pendidikan. Di sisi lain, Undang-undang Republik Indonesia Nomor 20 Tahun 2003 tentang Sistem Pendidikan Nasional menganut semangat sentralistik. Di satu sisi, dirumuskan pentingnya partisipasi masyarakat dalam suasana desentralistik.

Selanjutnya, menurut Benny Susanto sebagaimana dikutip Muhammad Rifai, kebijakan pembangunan nasional secara umum adalah mensukseskan terlaksananya otonomi daerah di bidang pendidikan dan kebudayaan dengan prioritas melanjutkan peningkatan, perluasan, pemerataan, kesempatan mendapatkan pendidikan, peningkatan mutu, efisiensi, dan efektivitas pengelolaan pendidikan dan kebudayaan. Namun di sisi lain, penguasa lebih mengutamakan tujuan/target daripada proses. Ada kecenderungan yang beraroma politis di dalamnya. Di satu sisi, ada upaya untuk meningkatkan kemampuan akademik dan professional serta meningkatkan kesejahteraan tenaga pendidik (guru) sehingga mampu melaksanakan tugasnya secara optimal. ${ }^{20}$

Dunia pendidikan nasional di zaman reformasi ini, diakui atau tidak memiliki karakter yang menenggelamkan gerakan intelektual bagi kemajuan pendidikan nasional. Kecenderungan birokrasi pada lembaga pendidikan yang rumit dalam memberikan

${ }^{19}$ Lihat Undang-undang Republik Indonesia Nomor 25 Tahun 2000 tentang Program Pembangunan Nasional (Propenas) Tahun 2000-2004, Propenas berisikan tentang (1) prioritas pembangunan nasional, (2) pembangunan hukum, (3) pembangunan ekonomi, (4) pembangunan politik, (5) pembangunan agama, (6) pembangunan daerah, (7) pembangunan sumber daya alam dan lingkungan hidup, dan (8) pembangunan pertahanan dan keamanan.

${ }^{20}$ Muhammad Rifai, Politik Pendidikan Nasional, 65. 
pelayanan terhadap masyarakat karena begitu banyaknya biro yang harus dilalui. Kesan mengutamakan aktivitas birokrasi inilah yang pada akhirnya mengesampingkan dunia intelektual. Mental birokrasi untuk memberikan pelayanan terhadap pengembangan dan gerakan intelektual ini menjadi sangat penting karena pengembangan dan gerakan intelektual di lembaga pendidikan memerlukan suasana dan kondisi yang sangat kondusif bagi munculnya kreativitas dan inovasi baru.

Peran birokrasi yang berwajah humanis dalam memberikan pelayanan kepada masyarakat di bidang pendidikan diharapkan sepenuhnya berperan vital, reformis, dinamis, inovatif, aspiratif, terbuka dan bersifat mengayomi. Di sini, Kementerian Pendidikan Nasional segera mengambil sikap dengan untuk melakukan inovasi dan pemikiran, mereformasi struktur dan mekanisme birokrasi yang kondusif untuk menciptakan pendidikan yang unggul, walau memerlukan anggaran yang tidak sedikit dan kemampuan sumber daya manusia yang kompeten di bidangnya.

Adapun Renstra Kemendiknas 2015-2019 Kementerian Pendidikan dan Kebudayaan Republik Indonesia yang disajikan dalam Rapat Koordinasi Pusat dan Daerah Direktur Jenderal Kebudayaan Hotel Mercure Ancol Jakarta, 16 April 2015 membahas tentang Indikator Keberhasilan Pembangunan Kebudayaan Kementerian Pendidikan dan Kebudayaan Tahun 2015-2019. Dalam naskah tersebut setidaknya dibahas materi-materi penting antara lain: (1) landasan hukum, (2) visi, (2) misi, (3) tujuan, (4) sasaran, dan (5) indikator keberhasilan. ${ }^{21}$

\section{Peran Birokrasi dan Partisipasi Masyarakat sebagai Kontrol Pendidikan Nasional}

Peran birokrasi dan partisipasi masyarakat sebagai kontrol pendidikan nasional merupakan fungsi birokrasi itu sendiri, mengontrol tugas pokok dan fungsi birokrasi pendidikan hingga pelaksanaan proses pendidikan di daerah supaya berjalan dengan baik. Menurut Tilaar, meningkatkan kemampuan kinerja birokrasi pendidikan dapat dilakukan melalui program pembinaan birokrasi pendidikan nasional yang profesional, ini dilakukan untuk menghapus stigma bahwa birokrasi merupakan kelompok yang

${ }^{21}$ Renstra Kemendiknas 2015-2019 Kementerian Pendidikan dan Kebudayaan Republik Indonesia. 
sangat sulit untuk berubah. Mereka cenderung menjadi orang yang konservatif dalam melaksanakan tugasnya (business as usual). ${ }^{22}$

Partisipasi masyarakat sebagai kontrol pendidikan nasional diamanatkan dalam Undang-undang Nomor 20 Tahun 2003 tentang Sistem Pendidikan Nasional melalui pembentukan dewan pendidikan baik pada tingkat pusat, provinsi dan kabupaten/kota. ${ }^{23}$ Dewan pendidikan tersebut merupakan lembaga yang independen yang antara lain dapat mengontrol jalannya pendidikan di daerah. Fungsi dewan pendidikan ini harus terus ditingkatkan baik mengenai mutu para anggotanya maupun mekanisme kerjanya di daerah maupun di pusat. ${ }^{24}$

Renaldo Deleon Paulus memberikan contoh yang berkaitan dengan "Implementasi Kebijakan di Dinas Pendidikan Kabupaten/Kota". Berikut deskripsi yang digambarkan Renaldo dalam tulisannya: "Dalam rencana kerja tahunan yang telah disusun oleh Dinas Pendidikan di suatu daerah, menjadi bahan Rencana Kerja Pemerintah Daerah (RKPD). Sebelum RKPD ditetapkan dengan peraturan Bupati/Walikota terlebih dahulu dilaksanakan Musyawarah Perencanaan Pembangunan (Musrenbang) di tingkat kabupaten/kota dan pembahasan antar unit kerja pemerintah daerah. Walaupun bentuknya pembahasan bersama tetapi tidak merubah kegiatan-kegiatan dalam rencana kerja (Renja) dari dinas pendidikan untuk menjadi RKPD Wawancara dengan Kepala Sub Bagian Program pendidikan Kabupaten/Kota. Musrenbang di tingkat kabupaten diselenggarakan oleh badan perencanaan kabupaten. Forum ini diikuti seluruh satuan kerja perangkat daerah serta melibatkan berbagai LSM di Kabupaten/kota. Untuk organisasi di luar pemerintah yang terkait dengan masalah pendidikan hanya Dewan Pendidikan Kabupaten/Kota yang diundang.

Proses kegiatan musrenbang tingkat kabupaten lebih mirip dengan sosialisasi RKPD yang akan ditetapkan dengan keputusan walikota. Khusus kegiatan yang terkait dengan masalah pendidikan lebih terjadi pada saat raker Dinas Pendidikan. Hal ini karena yang

${ }^{22}$ H.A.R Tilaar, Kekuasaan dan Pendidikan, 22.

${ }^{23}$ Dewan pendidikan adalah lembaga mandiri yang beranggotakan berbagai unsur masyarakat yang peduli pendidikan. Penjelasan mengenai Dewan Pendidikan dan Komite Sekolah/Madrasah dijabarkan dalam bagian tiga Pasal 56 butir 1-4. Undangundang Republik Indonesia Nomor 20 Tahun 2003 Tentang Sistem Pendidikan Nasional, 3, 18.

${ }^{24}$ H.A.R Tilaar, Kekuasaan dan Pendidikan, 22. 
dilibatkan dalam musrenbang tingkat kabupaten hanya Dewan Pendidikan Kabupaten/Kota yang sebelumnya telah mengikuti raker tahunan Dinas Pendidikan". 25

Menurut Zamroni, reformasi pendidikan pada era reformasi dewasa ini secara prinsip sebenarnya mengarah pada dua sasaran penting. Pertama reformasi pendidikan diarahkan untuk memberikan tanggungjawab lebih besar kepada birokrasi di daerah untuk secara langsung menangani pendidikan, dengan memobilisasi dukungan penuh masyarakat (desentralisasi). Kedua, reformasi ditujukan untuk meningkatkan dinamika internal sekolah/madrasah, dengan memberikan kesempatan lebih besar pada level sekolah: kepala sekolah, guru, orang tua siswa, staf administrasi dalam melaksanakan penyelenggaraan sekolah seharihari (otonomi sekolah) atau disebut juga dalam wujud Manajemen Berbasis Sekolah (MBS). ${ }^{26}$

Ekspektasi birokratis adalah tuntutan dan kewajiban formal yang ditetapkan oleh suatu organisasi termasuk di satuan lembaga pendidikan; ekspektasi birokratis merupakan bahan mentah utama dalam struktur organisasional. Peran birokratis ditentukan oleh serangkaian ekspektasi yang dileburkan ke dalam posisi dan jabatan di dalam suatu organisasi tertentu. Di lembaga sekolah, jabatan kepala sekolah, guru dan siswa sangatlah penting dan masingmasingnya didefinisikan berdasarkan serangkaian ekspektasi. Ekspektasi birokratis memerinci dan menetapkan perilaku yang semestinya/tepat bagi peran atau posisi tertentu. Seorang guru, mengemban kewajiban untuk merancang pengalaman belajar para siswa dan memiliki tugas untuk melibatkan para murid dengan cara yang efektif secara pedagogis. Peran dan ekspetasi birokratis merupakan cetak biru resmi bagi aksi, yang merupakan hadiah/fasilitas organisasi jabatan. ${ }^{27}$

Singkat kata, organisasi formal semisal sekolah memiliki struktur yang terdiri atas ekspektasi dan peran birokratis, sebuah hierarki jabatan dan posisi, aturan dan peraturan, serta spesialisasi.

${ }^{25}$ Renaldo Deleon Paulus, "Implementasi Kebijakan di Dinas Pendidikan Kabupaten Minahasa," Jurnal Eksekutif, Vol. 1, No. 1, 2013, 1-14.

${ }^{26}$ Zamroni, Pendidikan dan Demokrasi dalam Transisi (Prakondisi Menuju Era Globalisasi), (Jakarta: PSAP Muhammadiyah, 2007), 204.

${ }^{27}$ Wayne K. Hoy dan Cecil G. Miskel, Administrasi Pendidikan: Teori, Riset dan Praktek, diterjemahkan dari Educational Administration: Teory, Research and practice oleh Daryatno dan Rianayati K. Pancasari, (Yogyakarta: Pustaka Pelajar, 2014), 36. 
Ekspektasi birokratis mendefinisikan peran-peran organisasional; peran dileburkan ke dalam posisi dan jabatan. Adapun posisi dan jabatan disusun ke dalam sebuah hirarki kewenangan/otoritas formal yang sesuai dengan kekuasaan dan status relatifnya. Aturan dan peraturan ditetapkan untuk memandu pengambilan keputusan dan meningkatkan rasionalitas organisasional, sedangkan tenaga kerja dibagi-bagi sesuai dengan spesialisasi individu di dalam tugas. Perilaku di sekolah sebagian ditentukan oleh struktur organisasinya; sebagian struktur mempermudah dan sebagian yang lain menghambat fungsi sekolah.

Mitzberg sebagaimana dikutip oleh Wayne K. Hoy dan Cecil G. Miskel, "Administrasi Pendidikan: Teori, Riset dan Praktek" mengajukan serangkaian empat sistem kekuasaan internal sebuah birokratis yang menjadi sumber dasar untuk mengontrol kehidupan organisasional (contoh kekuasaan internal di institusi pendidikan sebagaimana uraian di atas), yaitu berupa sistem otoritas, sistem ideologi (iklim dan budaya), sistem kepakaran, dan sistem politik.

Berikut penjabaran keempat sistem tersebut di atas: (1) sistem otoritas merupakan arus formal kekuasaan melalui saluransaluran sah yang memungkinkan organisasi mencapai tujun-tujuan formalnya; (2) sistem ideologi; adalah serangkaian kesepakatan informal dikalangan guru tentang sekolah berikut hubunganhubungannya dengan kelompok-kelompok lain yang muncul sewaktu organisasi mengembangkan budayanya; (3) sistem kepakaran adalah hubungan timbal balik di kalangan pakar atau kaum profesional untuk memecahkan ketidakpastianketidakpastian darurat/genting yang dihadapi oleh organisasi; (4) sistem politik adalah jaringan politik organisasi yang tidak memiliki legitimasi dari tiga sistem kekuasaan lainnya. Sistem ini juga tidak memiliki konsensus dan peraturan. Politik bisa dilukiskan sebagai serangkaian permainan yang dimainkan oleh para pemilik kekuasaan. Permainan politik bisa hidup berdampingan dengan sistem-sistem yang sah, bermusuhan dengan sistem, atau menggantikan sistem-sistem kontrol yang sah. ${ }^{28}$

Peran birokrasi di lembaga sekolah/madrasah menjadi puncak model implementasi kebijakan, oleh karenannya diperlukan adanya pembaharuan manajemen pada satuan pendidikan. Proses pembaharuan tersebut berkaitan dengan pengembangan

${ }^{28}$ Wayne K. Hoy dan Cecil G. Miskel, Administrasi Pendidikan: Teori, Riset dan Praktek, 360-361. 
(development), penyebaran (diffusion), diseminasi (dissemination), perencanaan adopsi (adoption), dan penerapan (implementation). Model pembaharuan ini sebagaimana diungkap oleh Yoyon Bahtiar Irianto dikelompokkan ke dalam dua model, yaitu top-down model dan bottom-up model. ${ }^{29}$

Adapun model implementasi kebijakan sebagai wujud pembaharuan manajemen di satuan pendidikan menurut Yoyon antara lain mencakup: (1) broad base education (BBE), ${ }^{30}$ life skills, dan kurikulum berbasis kompetensi (KBK); (2) manajemen berbasis sekolah (MBS); (3) penguatan pendidikan luar sekolah (PLS) berbasis pkbm dan pkbm masyarakat; (4) kurikulum tingkat satuan pendidikan (KTSP) tahun 2006; (5) perguruan tinggi badan hukum milik negara (BHMN) menuju badan layanan umum (BLU); (6) pengembangan model profesi kependidikan; (7) kebijakan ujian nasional (UN); (8) antisipasi penolakan pembaharuan; (9) kebijakan sertifikasi guru dan dosen; (10) bantuan operasional sekolah (BOS); (11) pendidikan karakter (kurikulum 2010); (12) perubahan IKIP menjadi Universitas; (13) kurikulum berbasis tematik integratif 2013; dan lain-lain.

Model implementasi kebijakan di bidang pendidikan tersebut di atas dalam implementasinya harus menggunakan saluran-saluran komunikasi yang mendukung kelancaran suatu ide atau gagasan yang dapat dicerna dengan baik oleh masyarakat. Ideide tersebut disosialisasikan dalam bentuk desiminasi skala regional maupun nasional. Usaha ini diharapkan dapat memecah kebuntuan komunikasi yang kerap kali terjadi pada setiap kebijakan yang digulirkan sehingga menimbulkan gesekan bahkan konflik horizontal di masyarakat khususnya pemangku kepentingan di dunia pendidikan atau konflik vertikal dengan sang pembuat

\footnotetext{
${ }^{29}$ Yoyon Bahtiar Irianto, Kebijakan Pembaharuan Pendidikan: Konsep, Teori dan Model, (Jakarta: PT. RajawaliGrafindo Persada, 2012), 143.

30 Dengan berpijak pada Undang-undang Sistem Pendidikan Nasional, pendidikan berbasis masyarakat dalam konteks keIndonesiaan menunjuk pada pengertian yang bervariatif, diantaranya mencakup: (1) pendidikan luar sekolah yang diberikan oleh organisasi akar rumput (grassroot organization) misal seperti Pesantren dan LSM, (2) pendidikan yang diberikan oleh sekolah swasta atau yayasan, (3) pendidikan dan pelatihan yang diberikan oleh pusat pelatihan milik swasta, (4) pendidikan luar sekolah yang didirikan oleh pemerintah, (5) pusat kegiatan belajar masyarakat, (6) pengambilan keputusan yang berbasis masyarakat. Zubaedi, Pendidikan Berbasis Masyarakat: Upaya Menawarkan Solusi terhadap Berbagai Problem Sosial, (Yogyakarta: Pustaka Pelajar, 2005), 136.
} 
kebijakan hingga berujung pada ketidakpercayaan publik atas pemerintah itu sendiri.

Pemerintah sebagai pemegang amanah kekuasaan dari rakyat melalui undang-undang atau aturan yang diciptakannya dapat bersama-sama rakyat secara langsung menentukan formulasi kebijakan dan mengimplementasikan kebijakan tersebut.

\section{Simpulan}

Implementasi kebijakan dan peran birokrasi di bidang pendidikan dibutuhkan birokrasi pendidikan yang mampu beradaptasi dengan dinamika perubahan lingkungan dan memahami kebutuhan masyarakat yang dilayaninya. Kinerja birokrasi melalui responbilitas harus terus ditingkatkan untuk menciptakan pelayanan prima terutama merespon kepentingan publik. Lembaga pendidikan membutuhkan penghargaan dan perlakuan humanis ketimbang dijadikan sasaran ekploitasi dan kepentingan politis etis semata yang menegasikan tujuan utama dari pendidikan itu sendiri.

Peran birokrasi di lembaga sekolah pada akhirnya menjadi puncak model implementasi kebijakan pada satuan dan jenjang pendidikan. Di sini diperlukan adanya pembaharuan manajemen pada satuan dan jenjang pendidikan tersebut. Proses pembaharuan atau inovasi manajemen menjadi suatu keniscayaan untuk menyelesaikan persoalan-persoalan yang tengah dihadapi. Problem-problem tersebut dapat berupa usaha pemerataan pendidikan, peningkatan mutu, peningkatan efisiensi dan efektifitas pendidikan serta relevansi pendidikan. Tujuannya agar supaya penyebaran ide-ide inovasi yang dilakukan bisa diadopsi, dimanfaatkan dan didesiminasikan untuk perbaikan dan pemecahan problematika pendidikan di Indonesia.

\section{Referensi}

Dwiyanto, Agus dkk. Reformasi Birokrasi Publik di Indonesia. Yogyakarta: Penerbit PSKK-UGM, 2002.

Fatah, Nanang. Analisis Kebijakan Pendidikan. Bandung: PT. Remaja Rosdakarya, 2013. 
H.A.R. Tilaar. Kekuasaan dan Pendidikan: Manajemen Pendidikan Nasional dalam Pusaran Kekuasaan. Jakarta: PT. Rineka Cipta, 2009.

Hoy, Wayne K. dan Miskel, Cecil G. Administrasi Pendidikan: Teori, Riset dan Praktek, diterjemahkan dari Educational Administration: Teory, Research and Practice oleh Daryatno dan Rianayati K. Pancasari. Yogyakarta: Pustaka Pelajar, 2014.

Irianto, Yoyon Bahtiar. Kebijakan Pembaharuan Pendidikan: Konsep, Teori dan Model. Jakarta: PT. RajawaliGrafindo Persada, 2012.

M. Hadjon, Philipus dkk. Pengantar Hukum Administrasi Indonesia (Introduction to the Indonesian Administrative Law). Yogyakarta: Gadjah Mada University Press, 2008.

Munadi, Muhammad dan Barnawi. Kebijakan Publik di Bidang Pendidikan. Yogyakarta: Ar-Ruzz Media, 2011.

Nawawi, Zaidan. Manajemen Pemerintahan. Jakarta: PT. Raja Grafindo Persada, Renaldo Deleon. "Implementasi Kebijakan di Dinas Pendidikan Kabupaten Minahasa" dalam Jurnal Eksekutif, 2013 - ejournal.unsrat.ac.id. 2013.

Renstra Kemendiknas 2015-2019 Kementerian Pendidikan dan Kebudayaan Republik Indonesia.

Rifai, Muhammad. Politik Pendidikan Nasional. Yogyakarta: Ar-Ruzz Media, 2011.

Rohman, Arif. Politik Ideologi Pendidikan. Yogyakarta: LaksBang Mediatama, 2009.

Sa"ud, Syaefudin dan Abin Syamsuddin Makmun. Perencanaan Pendidikan: Suatu Pendekatan Komprehensif. Bandung: PT. Remaja Rosdakarya, 2006.

Sumarjo, Endro. "Aktualisasi Nilai-nilai Good Governance dalam Penyelenggaraan Pemerintah dan Pembangunan" dalam Jurnal Hukum dan HAM Bidang Pendidikan Vol. 2 No. 1 April 2004 ISSN 1693-4512.

Undang-undang Republik Indonesia Nomor 20 Tahun 2003 Tentang Sistem Pendidikan Nasional. 
JIEMAN: Journal of Islamic Educational Management

Undang-undang Republik Indonesia Nomor 25 Tahun 2000 tentang Program Pembangunan Nasional (PROPENAS) Tahun 2000-2004.

Zamroni. Pendidikan dan Demokrasi dalam Transisi (Prakondisi Menuju Era Globalisasi). Jakarta: PSAP Muhammadiyah, 2007.

Zubaedi. Pendidikan Berbasis Masyarakat: Upaya Menawarkan Solusi terhadap Berbagai Problem Sosial. Yogyakarta: Pustaka Pelajar, 2005. 